\title{
Exploring How Intangibility Affects Perceived Risk
}

By: Michele Laroche, Gordon H.G. McDougall, Jasmin Bergeron, and Zhiyong Yang

Laroche, Michel, Gordon H.G. McDougall, Jasmin Bergeron, and Zhiyong Yang (2004), "Exploring How Intangibility Affects Perceived Risk," Journal of Service Research, 6(4), 373389. https://doi.org/10.1177/1094670503262955

****(C) 2004 Sage Publications. Reprinted with permission. No further reproduction is authorized without written permission from SAGE. This version of the document is not the version of record. Reuse is restricted to non-commercial and no derivative uses. $* * *$

\begin{abstract}
:
Studies have found that product intangibility increases consumers' perception of risk. However, most of these studies measured the intangibility and perceived risk constructs unidimensionally. The primary objective of this article is to examine the effects of the multiple dimensions of intangibility on the various types of risk. An empirical investigation revealed that, of the three intangibility dimensions, physical intangibility was the least correlated to the consumers' perception of risk in most situations, whereas mental intangibility and generality had a great impact on most dimensions of perceived risk. However, there were variations in the strength of the relationships between the intangibility dimensions and the risk dimensions when contrasting goods and services, generic products and brands, and online and offline purchase contexts. Theoretical and practical contributions to the service marketing literature are discussed.
\end{abstract}

Keywords: intangibility | perceived risk | services marketing | structural equation modeling

\section{Article:}

Two central concepts in marketing are intangibility and perceived risk. Both influence consumer decision making and marketing strategy. Intangibility, the major characteristic that distinguishes goods from services, affects the consumer's ability to judge the quality of the good/service. The more intangible a product is, the more difficult its evaluation will be (Zeithaml 1981). Perceived risk, the uncertainty and consequences of the decision, affects the extent of search and information sought (Bauer 1960). In response, marketing strategies include branding (to increase tangibility) and guarantees (to reduce risk), and a host of other initiatives have been implemented to influence consumer behavior.

Intangibility is one of the main influences on perceived risk. As intangibility increases, so does perceived risk (Murray and Schlacter 1990). Typically, intangibility has been defined as the lack of physical evidence (McDougall 1987). Recent research empirically examined the conceptual definition of intangibility and found that it was composed of three distinct dimensions: physical intangibility, generality, and mental intangibility (Laroche, Bergeron, and Goutaland 2001). Perceived risk has multiple dimensions as well, including social, financial, physical, psychological, time, and performance risks (Stone and Gronhaug 1993). 
The major objective of this article is to investigate the impact of the three intangibility dimensions on five dimensions of perceived risk across different product categories and brands for both goods and services (Figure 1).

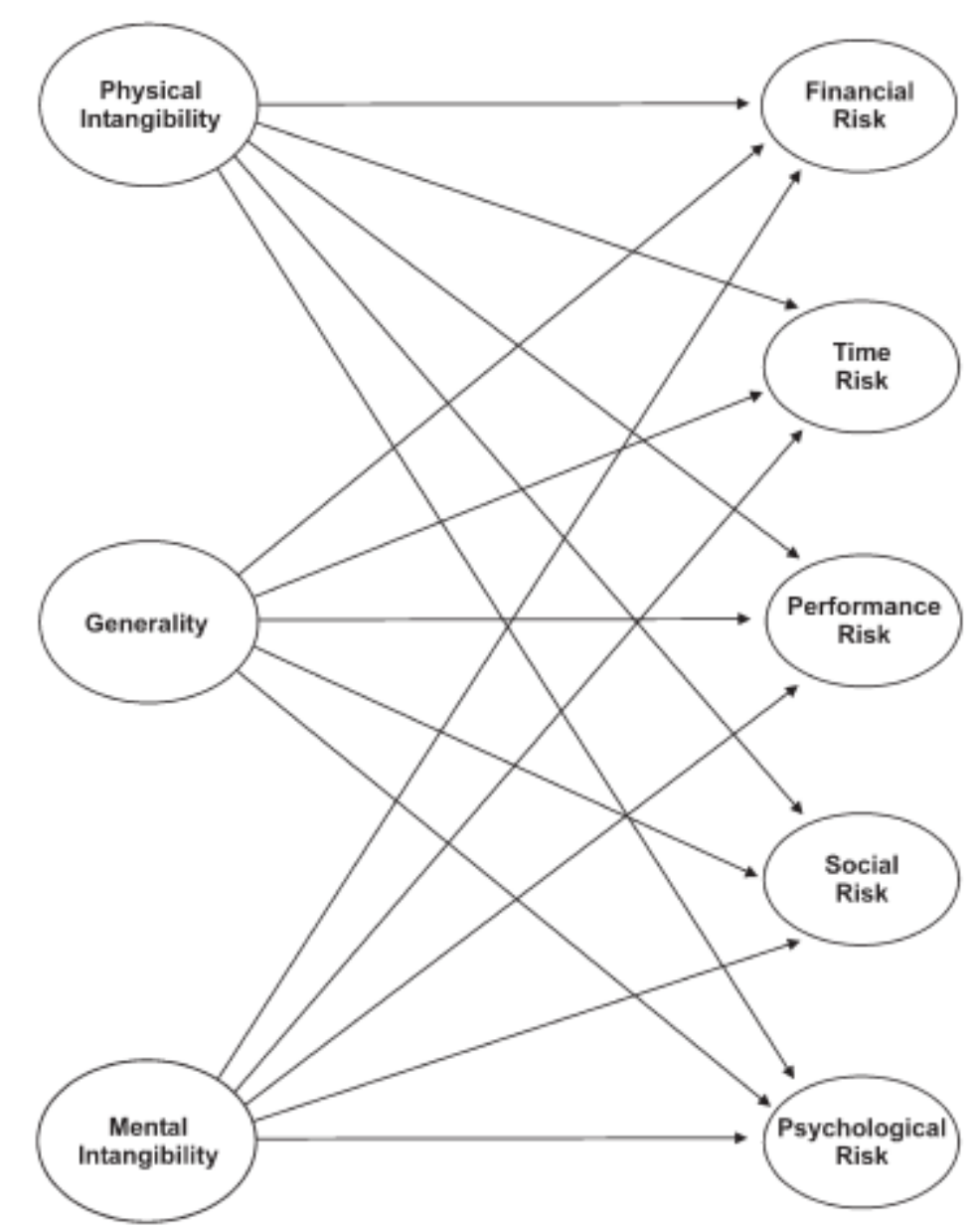

Figure 1. The Intangibility-Perceived Risk Model

A second objective of this research is to compare the relationship between intangibility and perceived risk in the online versus the offline environments. With the advent of the Internet, new forms of goods and services and delivery channels have appeared. For example, music and banking services can be directly delivered in a digital, nonphysical format by a firm that has no physical presence. Traditionally, these forms and channels are believed to be more intangible and increase perceived risk. However, recent studies show that the Internet, despite being a fairly intangible medium, is currently used as a means of tangibilizing the intangible (Berthon et al. 1999). Some researchers attribute this phenomenon to the powerful function of the Internet in easily providing consumers with appropriate information and in lessening the efforts needed in making purchase decisions (Thakor, Borsuk-Shtevi, and Kalamas forthcoming). Therefore, identifying the degree to which the online versus the offline environments may increase or decrease intangibility and perceived risk can provide insights to marketing managers involved in the online environments. 
It is hoped the article will make the following contributions to the marketing field. First, the present study extends the understanding of intangibility and perceived risk in three ways: (a) by using multiple dimensions for both intangibility and perceived risk; (b) by direct modeling of intangibility and perceived risk to identify the relationships between the individual dimensions of intangibility and those of perceived risk; and (c) by testing these relationships across goods, services, brands, generic products, and purchase situations to increase the generalizability of the results. The study will extend the understanding of the relationship between intangibility and perceived risk beyond the general statement that increased intangibility leads to increased perceived risk. Second, the study offers managerial implications to address the situations where intangibility and perceived risk are most likely to occur. Globally, it is hoped that this investigation will provide both theoretical and practical contributions to understanding the impact of intangibility on perceived risk.

\section{LITERATURE REVIEW}

\section{Intangibility}

Intangibility has been defined as "impalpable" and "not corporeal" (Shostack 1977); "that which cannot be easily defined, formulated or grasped mentally" (Berry 1980); and "the lack of physical evidence" (McDougall 1987). According to the Oxford Dictionary of Current English (1996), intangibility is (a) that which cannot be touched or seen, (b) that which is difficult to define or describe clearly, and (c) that which cannot be easily grasped mentally. Prior research has tended to view intangibility as a single dimension related to the lack of physical evidence (Bebko 2000; Finn 1985) or a two-dimensional construct related to the lack of physical evidence and generality - how general or specific a consumer perceives a particular good or service (Breivik, Troye, and Olsson 1998).

Recent research suggests the intangibility construct encompasses three dimensions: physical intangibility, generality, and mental intangibility (Laroche, Bergeron, and Goutaland 2001). The physical dimension represents the extent to which a good cannot be touched or seen; it is inaccessible to the senses and lacks a physical presence. The generality dimension refers to the customer's difficulty in precisely defining or describing a particular good. Flipo (1988) argued that the word tangible is often used as a synonym of precise. Making a tangible promise, for instance, implies saying precisely what one commits oneself to do. Goods can be perceived as general if consumers cannot refer precisely to identifiable definitions, features, and/or outcomes (e.g., a car is a complex vehicle that one uses to get from Point A to Point B) (Laroche, Bergeron, and Goutaland 2001). Inversely, goods are perceived as specific if they generate numerous clear-cut definitions, features, and/or outcomes in the consumer's mind (e.g., a car is an intricate machine; made of aluminum alloy; powered by an internal-combustion engine; with numerous features such as antilock braking systems, dual-side air bags, immobilizer theftdeterrent devices, air conditioning, etc.).

Mental intangibility reflects the fact that a good can be physically tangible, but difficult to grasp mentally. According to McDougall and Snetsinger (1990), physical tangibility does not ensure a clear, mentally tangible representation of an object, especially if the evaluator lacks experience with that object. For example, a car engine is probably mentally intangible for most people, that 
is, for those who do not have sufficient knowledge to appreciate its mechanics. The threedimensional intangibility scale will be used in this study.

\section{Perceived Risk}

Perceived risk is an important construct in the social sciences with a rich and varied history of research (Campbell and Goodstein 2001). Bauer (1960) introduced the idea that consumer behavior be considered as an instance of risk-taking and risk-reducing behavior. The extensive research on perceived risk (see Dowling 1999; Dowling and Staelin 1994; Mitchell 1999 for reviews) has shown that consumers' perceptions of risk are central to their evaluations and purchasing behaviors (Dowling 1999).

Perceived risk has two components: uncertainty (the likelihood of unfavorable outcomes) and consequences (the importance of a loss) (Bauer 1960). Different types of risk exist, namely, financial, performance, time, physical, psychological, and social risks (Havlena and DeSarbo 1990; Jacoby and Kaplan 1972; Murray and Schlacter 1990), and the importance of each varies across product categories (Jacoby and Kaplan 1972; Kaplan, Szybillo, and Jacoby 1974). That is, the perceived risk for two different product purchases may both be high, but in one case-for example, a computer - performance and financial risks are high, whereas the remaining risks may be low. In the next case - for example, an Internet browser - the time and performance risks are high. The point is that the dimensions of risk are very product specific and can be independent of each other.

Here, perceived risk is viewed as a subjective expectation of loss (Mitchell and Greatorex 1993; Peter and Ryan 1976). Briefly, social risk can be defined as the potential loss of esteem, respect, and/or friendship offered to the consumer by other individuals (Murray and Schlacter 1990) and is more likely to occur with services because of the service encounter (Mitchell and Greatorex 1993; Murray and Schlacter 1990). Time risk is the potential loss of time and effort associated with purchasing the item (Murray and Schlacter 1990). Psychological risk is the potential loss of self-image or self-concept as the result of the item purchase (Murray and Schlacter 1990).

Financial risk is the potential loss of money associated with the item purchase, and performance risk is the potential loss due to item failure after purchase.

It is important to understand how each of the risk dimensions contributes to overall risk both from theoretical and practical viewpoints. From a theoretical viewpoint, the risk dimensions will affect the type of information sought, the information sources used, and the length of time in the decision process. From a practical viewpoint, the marketing strategies used to reduce risk will be far more effective if the contributions of each of the risk dimensions to overall risk is well understood.

Perceived risk also varies across methods of shopping. Nontraditional shopping may have higher risk than traditional shopping (Gillett 1976), and buying by phone or mail may be more risky than buying in retail stores (Cox and Rich 1964; Spence, Engel, and Blackwell 1970). Bobbitt and Dabholkar (2001) proposed that some types of risk, such as financial, psychological, and performance risks are more applicable to shopping on the Internet than other nontraditional or traditional shopping methods. For example, in terms of financial risk, consumers may fear that 
the company that they "know" only through the Internet may misuse their credit cards. Psychological risk may occur because Web sites can capture personal information, and there is some psychological risk associated with not knowing the entity from which you are buying. Performance risk may occur when consumers purchase a good through the Internet but do not receive the good that was advertised. A five-dimensional perceived risk scale will be used in this study.

\section{Intangibility and Perceived Risk}

Research has shown that intangibility is positively correlated with perceived risk (De Ruyter, Wetzels, and Kleijnen 2001; Finn 1985; McDougall and Snetsinger 1990; Mitchell and Greatorex 1993; Murray and Schlacter 1990; Zeithaml and Bitner 2000). The lack of information available in making services versus goods decisions increases the risk (Bebko 2000). Also, services tend to be perceived as riskier to purchase than goods (McDougall and Snetsinger 1990; Mitchell and Greatorex 1993; Murray and Schlacter 1990). The properties of services - that is, heterogeneity, perishability, inseparability, and intangibility - may lower consumer confidence and increase perceived risk, mainly by augmenting the degree of uncertainty in the decision (Mitchell 1999).

A review of the literature found no studies that related the dimensions of intangibility to the dimensions of perceived risk. This is not surprising given the recent development of the threedimensional intangibility scale (Laroche, Bergeron, and Goutaland 2001). The implication is that there is little direct empirical or theoretical work to hypothesize the relationships that might exist between the dimensions of intangibility and perceived risk. The hypotheses, presented below, should be regarded as exploratory in nature.

\section{HYPOTHESES}

While intangibility is generally related to perceived risk, the relationships between the three dimensions of intangibility and the five dimensions of perceived risk have not been tested. Given the exploratory nature and objectives of this research, the major hypothesis is a test of the overall intangibility-perceived risk model (Figure 1).

Hypothesis 1: The three dimensions of intangibility will be significantly related to the five dimensions of perceived risk.

Branding has been used as a risk-reducing strategy and is often recommended for services, where higher risk exists (Berry 2000). Both theory and empirical evidence support the concept that brands, as opposed to generic products, should have lower risk (Mitchell and Greatorex 1993; Roselius 1971). For example, consumers may feel there is a great deal of risk associated with the generic product class; however, they may buy their favorite brand with confidence (Dowling and Staelin 1994). Dowling and Staelin referred to this distinction as product-category and productspecific risks. In a comparison of the relationships between intangibility dimensions and perceived-risk dimensions for generic products versus brands, the generic product model should provide a stronger relationship (i.e., higher standardized coefficients) than the brand model. 
Hypothesis 2: The intangibility-perceived risk relationship will be stronger with generic products versus brands.

Services and goods have been arrayed on a tangibility continuum where goods, because of high search qualities, are placed on the tangible end of the continuum (Shostack 1977). Goods and services high in experience qualities are placed in the middle, and services high on credence qualities are placed on the intangible end of the continuum (Shostack 1977; Zeithaml 1981). Because goods are high on search qualities and usually have a physical presence, both physical and mental intangibility should be low. Services should have higher physical and mental intangibility.

Hypothesis 3: The relationship between physical intangibility and the perceived risk dimensions will be stronger with goods versus services.

Hypothesis 4: The relationship between mental intangibility and the perceived risk dimensions will be stronger with services versus goods.

As noted earlier, with the Internet, new forms of goods and services and delivery channels have appeared. Often, these forms and channels are more intangible and may increase perceived risk. A closer look at the previous studies of online purchasing shows that privacy and security concerns are two most widely used antecedents of perceived risk (Hoffman, Novak, and Peralta 1999; Miyazaki and Fernandez 2001), but the effect of intangibility of the attributes of goods and services on perceived risk is rarely addressed. A recent study (Thakor, Borsuk-Shtevi, and Kalamas forthcoming) reported that the Internet, despite its intangible attributes as a purchase mode, provides and offers consumers proper access to and screening of appropriate information to minimize their search efforts in the purchase decision process. The improved efficiency at distributing, categorizing, and screening information in an online environment (e.g., Alba et al. 1997) should help diminish the mental intangibility of the product and therefore the perceived risk associated with the purchase. This increased access to specific, organized information would also allow consumers to familiarize themselves with more specific attributes and functions of the services or goods that they are purchasing, thus diminishing the impact of generality on the perceived risk associated with the transaction.

Hypothesis 5: The intangibility-perceived risk relationship will be weaker with the online situation versus the offline situation.

\section{METHOD}

\section{Product Selection}

Both generic products and brands within the categories were selected for this investigation. Six different product categories were chosen to increase the external validity of the study. They were selected based on three criteria. First, the products should be familiar to the student population from which the sample was selected. Second, products were chosen based on their expected variability along the perceived-risk and intangibility dimensions. Third, the products had to generate different types of risk. On the basis of these guidelines, the following generic products 
(brands) were selected: jeans (Levi's), computers (IBM), compact discs (Beatles), Internet browsers (Netscape), pizzeria dinners (Pizza Hut), and checking accounts (Royal Bank).

A pretest revealed that these products were characterized by various degrees of intangibility and that they involved different types of risk. Jeans and computers were thought of as highly tangible goods, whereas music CDs were perceived as less tangible goods. Pizzeria dinners were judged as a tangible service, whereas checking accounts and Internet browsers were thought of as intangible services. The selected products also varied along the dimensions of perceived risk. For example, a pair of jeans presented more performance risk, compared to a computer that entailed financial and performance risks or an Internet browser that involved more time risk.

\section{Survey Instrument}

A structured, nondisguised questionnaire was developed. Two versions of the questionnaire were used, each dealing with three of the six products in order to minimize respondent fatigue. To reduce order effects, two versions of each questionnaire were used with the products presented in reverse order. For example, the questionnaire that examined the purchase of a computer, a checking account, and a compact disc had a reciprocal counterpart that examined the purchase of a compact disc, a checking account, and a computer. These four versions were also adapted for brands (in addition to generic products) and for online purchases (in addition to offline purchase), for a total of 16 different versions. The versions with brands had the brand names added to the instructions and in the body of the questions where appropriate (e.g., Levi's jeans). The versions that dealt with offline purchases mentioned the brick-and-mortar situation (e.g., music store for a CD purchase) in the instructions and in the body of the questions where appropriate. The versions that dealt with the online situation had the word online clearly specified in the instructions and in the body of the questions where appropriate (e.g., online purchase of jeans).

The questionnaires were divided into four subsections. The first three examined the consumer perceptions for the three different goods or service classes (brands). Each section dealt with the consumer perceptions of one good or service (brand). The fourth section (common to all 16 versions) was included to gather general demographic information about each respondent.

Each questionnaire was pretested with students, and written comments were encouraged during the completion of the questionnaire. Following this procedure, minor modifications were made to the wording of the questions to improve clarity.

\section{Sampling Procedures}

Self-administered questionnaires were completed by a convenience sample of 783 college students at a northeastern university. Surveys were collected immediately upon completion, which yielded a total of 662 usable questionnaires, each dealing with three goods and/or services. Because, in testing the general model, we were interested in the aggregated responses to each product, this became the unit of analysis, and the sample size was then 1,986 responses. Eightyfive cases either with missing variables or considered as outliers were further discarded from the study; therefore, the remaining 1,901 observations were included in the final analysis. An outlier 
was identified if it met the two conditions simultaneously: (a) It gave the largest contribution to normalized multivariate kurtosis, and (b) it changed the estimates of the model after its deletion.

College students were deemed appropriate participants for this research because they are familiar and/or concerned with the type of products studied and because theory is being tested and developed (Calder, Phillips, and Tybout 1981). Analyses of demographic information suggest that the sample was representative of the student population in terms of gender (approximately $53.6 \%$ female students), age ( $94 \%$ were less than 30 years old), and education level (94\% were undergraduate students).

Measurement

Intangibility. The Intangibility Scale developed and validated by Laroche, Bergeron, and Goutaland (2001) was used. This scale demonstrated strong reliability and validity (convergent and discriminant) properties. Modifications were made to the generality scale based on the previous research (Laroche, Bergeron, and Goutaland 2001). The modified scale more adequately reflected the conceptual definition of generality (i.e., products are perceived as general if consumers cannot refer precisely to identifiable definitions, features, and/or outcomes). The items are presented in Appendix A.

Perceived risk. Five different types of risk were measured in this study: financial, time, performance, social, and psychological. The Perceived Risk Scales developed by Stone and Gronhaug (1993) were used in this investigation. The scales demonstrated good reliability and validity and were built on prior work (Stem, Lamb, and MacLachlan 1977). Three items were employed to measure each risk dimension. For each of the $15(3 \times 5)$ items, 9-point bipolar scales ranging from strongly disagree to strongly agree were used. The items were worded accordingly to the product investigated. For instance, the item "If I used an Internet browser ..." was modified to "If I ate a pizza ..." or "If I wore jeans. . .." One item with poor loadings on the respective factors $(<.50)$ was dropped out from the social risk construct (Pedhazur and Schmelkin 1991). A summary of the items used to measure each construct are presented in Appendix A.

\section{ANALYSES AND RESULTS}

\section{Product Selection Check}

As a check on the product selection, the means of the goods and services ratings were compared using the intangibility and risk measures (Figure 2 and Appendix B). For goods, as expected, the ratings of jeans and computers on the Physical Intangibility Scale did not show a significant difference $\left(M_{\text {jeans }}=1.95\right.$ vs. $\left.M_{\text {Computers }}=2.00, t=.39, p>.15\right)$, but they were significantly lower than the ratings of music CDs $\left(M_{\mathrm{CDs}}=2.39, F_{2,962}=7.46, p=.00\right)$. A further examination showed that music CDs and computers were perceived to have similar levels of generality and mental intangibility $(p>.05)$, whereas jeans were more tangible than either CDs or computers (Generality: $M_{\text {jeans }}=2.92$ vs. $M_{\mathrm{CDs}}=3.57, t=4.29, p=.00$; Mental Intangibility: $M_{\text {jeans }}=2.38$ vs. $\left.M_{\mathrm{CDs}}=2.89, t=3.48, p=.00\right)$. Computers were perceived to be the most risky purchase, whereas music CDs were considered the least risky transaction across four out of the five risk 
dimensions (Financial Risk: $F_{2,962}=69.61, p=.00$; Performance Risk: $F_{2,}, 962=67.40, p=.00$; Social Risk: $F_{2,962}=33.50, p=.00$; Psychological Risk: $\left.F_{2,962}=15.30, p=.00\right)$. The ratings of the Time Risk Scale were not statistically different across groups $\left(F_{2,962}=2.73, p>.05\right)$.
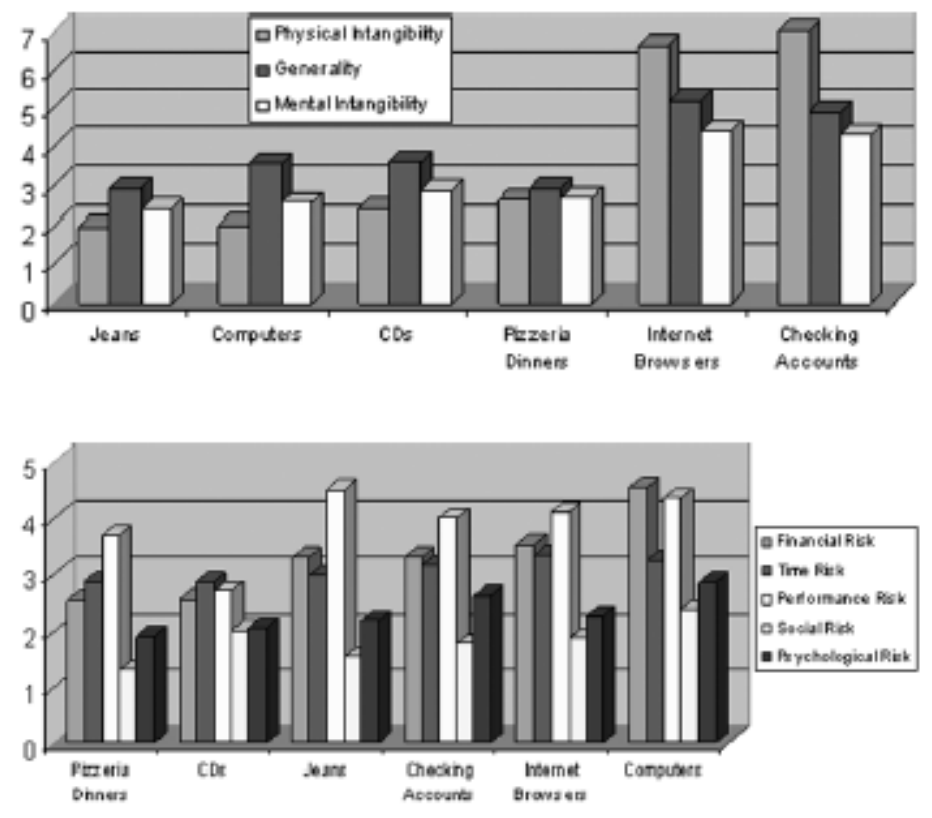

Figure 2. Ratings of Goods and Services on the Intangibility and Perceived Risk Scales

For services, pizzeria dinners were perceived as the most tangible service, with ratings much lower than those of Internet browsers and checking accounts on all intangibility scales (Physical Intangibility: $M_{\text {pizzeria }}=2.61, M_{\text {browsers }}=6.62$, and $M_{\text {checking }}=7.06$; Generality: $M_{\text {pizzeria }}=2.91$, $M_{\text {browsers }}=5.20$, and $M_{\text {checking }}=4.92, F_{2,933}=99.61, p=.00 ; M_{\text {pizzeria }}=2.70, M_{\text {browsers }}=4.41$, and $\left.M_{\text {checking }}=4.32, F_{2,933}=61.90, p=.00\right)$. As expected, checking accounts obtained the highest rating on the Physical Intangibility Scale $(t=2.38, p<.05)$ and the same rating as Internet browsers on the other two intangibility dimensions (Generality: $t=-1.55, p>.10$; Mental Intangibility: $t=-.48, p>.15$ ). A look at the differences on risk measures revealed that Internet browsers were perceived as risky as checking accounts $(p>.05)$, yet more risky than pizzeria dinners on financial risk $\left(F_{2,933}=17.63, p=.00\right)$, time risk $\left(F_{2,933}=3.69, p=.25\right)$, social risk $\left(F_{2,933}=23.30, p=.00\right)$, and psychological risk $\left(F_{2,933}=10.74, p=.00\right)$, but not on performance risk $\left(F_{2,933}=2.65, p>.05\right)$. Overall, the selected goods and services have the expected variability in intangibility and perceived-risk dimensions.

Testing the Measurement Models

Prior to testing the intangibility-perceived risk model, the reliability and validity of both the Intangibility and Perceived Risk Scales were examined. Statistical procedures used to validate the scales included assessment of construct reliability, convergent validity, and discriminant validity. In view of well-documented deficiencies of exploratory factor analyses and principal components analyses (see, e.g., Fornell 1983; Gorsuch 1990), the psychometric properties of the final measures were assessed by means of confirmatory factor analyses using the AMOS software (Arbuckle 1997), which uses the maximum-likelihood estimation method to examine 
the fit of models to their respective observed variance-covariance matrices. Different indicators can be used to assess the overall fit qualities of a model using structural equations modeling. Historically, the chi-square value has been the initial estimator of one model's fit (Bollen 1989; Browne and Cudeck 1989); however, researchers have recently recommended modified versions of the chi-square (Gerbing and Anderson 1993) because it is very sensitive to sample size and statistical power. Alternatively, acceptable model fits are indicated by both relative (standardized $\chi^{2}\left[\chi^{2} / d f\right]$, Goodness-of-Fit Index [GFI], Incremental Fit Index [IFI], and Comparative Fit Index $[\mathrm{CFI}]$ ) and absolute (root mean square error of approximation [RMSEA]) indexes. The cutoff value suggested for an adequate fit is GFI, IFI, and CFI greater than .90 (Bentler 1992); $\chi^{2} / d f$ values smaller than 5 (Taylor and Todd 1995); and RMSEA smaller than .05 (Browne and Cudeck 1989).

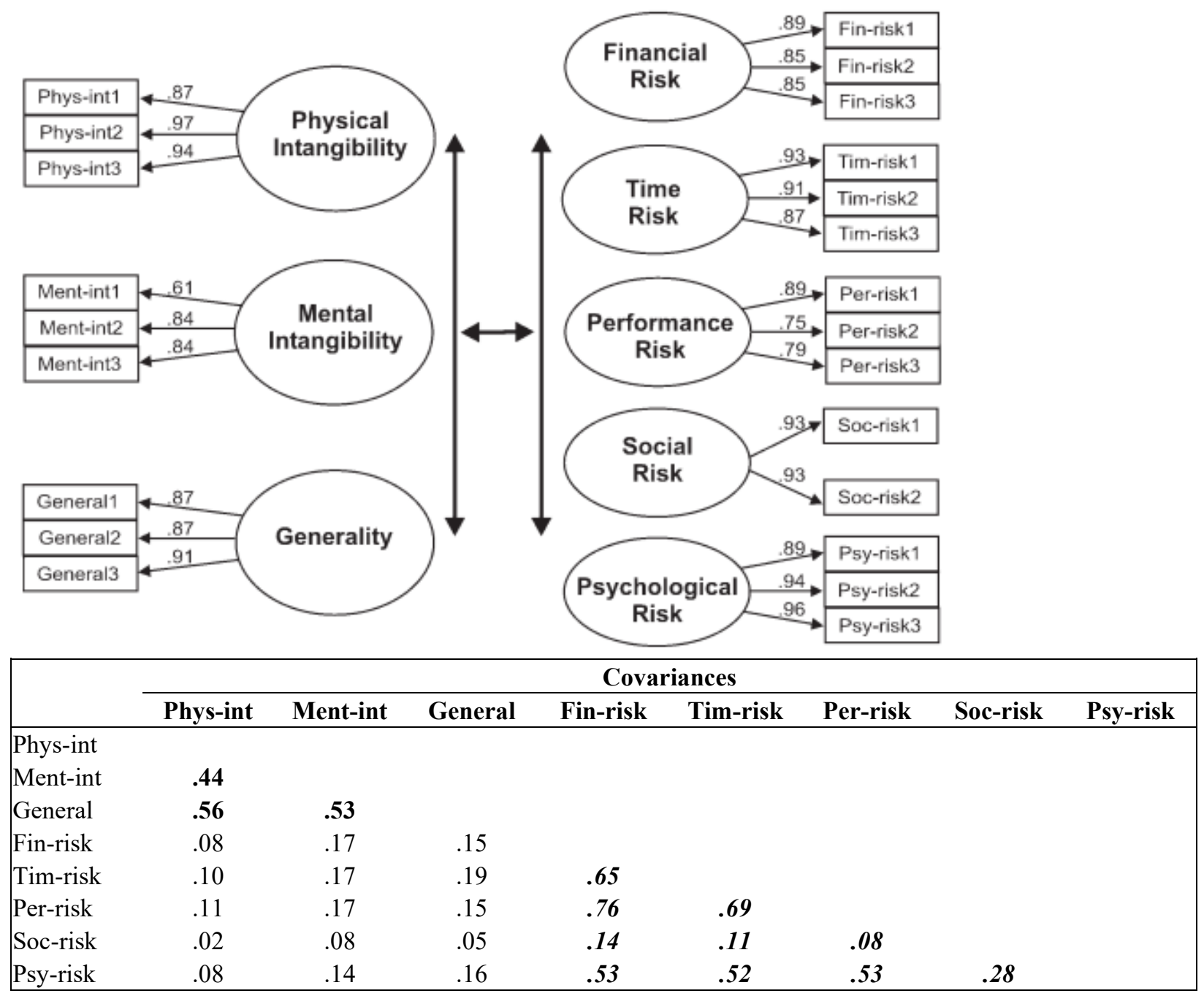

NOTE: Arrows in the figure represented for the covariance among those eight constructs. The actual estimates of covariances of Intangibility Scales and Perceived Risk Scales were shown below the figure. Every estimated coefficient was statistically significant $(p<.05)$. Covariances among intangibility dimensions were in boldface. Covariances among risk dimensions were in italic boldface. Phys-int is physical intangibility, Ment-int is mental intangibility, and General is generality, Fin-risk is financial risk, Tim-risk is time risk, Per-risk is performance risk, Soc-risk is social risk, and Psy-risk is psychological risk. $\chi^{2}(200, N=1,901)=894.3, p<.001, \chi^{2} / d f=4.4$, Goodness-of-Fit Index $(\mathrm{GFI})=.96$, Incremental Fit Index $(\mathrm{IFI})=.98$, Comparative Fit Index $(\mathrm{CFI})=.98$, RMSEA $=$ .04 . 
The measurement model with three dimensions of intangibility and five dimensions of perceived risk was examined and resulted in the following acceptable fit indexes: $\chi^{2}(200, N=1,901)=$ $894.3, p<.001 ; \chi^{2} / d f=4.4, \mathrm{GFI}=.96, \mathrm{IFI}=.98, \mathrm{CFI}=.98, \mathrm{RMSEA}=.04$, as shown in Figure 3.

Fornell and Larcker's (1981) procedures were followed to evaluate convergent and discriminant validity. Convergent validity is established if the average variance extracted for each factor accounts for .50 or more of the total variance. As shown in Table 1, the average variance extracted for the factors was as follows: .86 for physical intangibility, .78 for generality, and .59 for mental intangibility. Overall, convergent validity was confirmed for each dimension. Moreover, Anderson and Gerbing (1988) noted that convergent validity is demonstrated by statistically significant path coefficients. In this study, all coefficients are significant at the $p<$ .05 level.

Table 1. Tests for Convergent and Discriminant Validity of the Intangibility Dimensions

\begin{tabular}{|lccc|}
\hline Construct & Physical Intangibility & Generality & Mental Intangibility \\
\hline Physical intangibility & .86 & & \\
Generality & .32 & .78 & .59 \\
Mental intangibility & .20 & .28 & \\
\hline
\end{tabular}

NOTE: The diagonal entries show Fornell and Larcker's (1981) index of the average variance extracted by the construct. Entries below the diagonal represent squared correlation coefficients.

According to Fornell and Larcker (1981), discriminant validity is established if the average variance extracted is larger than the squared correlation coefficients between factors. Results in Table 1 show that this criterion was met across all pairs of factors. Furthermore, results from LaGrange Multiplier (LM) tests indicated no significant cross-loadings for measurement items with nonhypothesized constructs, thus supporting discriminant validity. Thus, the threedimensional Intangibility Scale is a reliable and valid instrument.

These same statistical procedures were also used for the Perceived Risk Scale (Table 2). Convergent validity is satisfactory because the average variance extracted for each risk dimension accounted for more than .5 of the total variance (between .66 and .87 ). Moreover, the average variance extracted for each of the five dimensions exceeded the squared correlation between the respective pair of constructs, providing evidence of discriminant validity. Thus, the Perceived Risk Scale is a reliable and valid measurement instrument.

Table 2. Tests for Convergent and Discriminant Validity of the Perceived Risk Dimensions

\begin{tabular}{|lccccc|}
\hline Construct & Financial Risk & Time Risk & $\begin{array}{c}\text { Performance } \\
\text { Risk }\end{array}$ & Social Risk & $\begin{array}{c}\text { Psychological } \\
\text { Risk }\end{array}$ \\
\hline Financial risk & .74 & & & & \\
Time risk & .42 & .82 & & & \\
Performance risk & .58 & .48 & .66 & .86 & \\
Social risk & .02 & .01 & .01 & .08 & .87 \\
Psychological risk & .28 & .27 & .28 & .28 \\
\hline
\end{tabular}

NOTE: The diagonal entries show Fornell and Larcker's (1981) index of the average variance extracted by the construct. Entries below the diagonal represent squared correlation coefficients. 
The structural model specified the hypothesized causal relationships between the three dimensions of intangibility and the five dimensions of perceived risk (see Figure 1). The overall GFI statistics of the general model suggested that the proposed model was consistent with the data according to relative (GFI, IFI, and CFI) and absolute (RMSEA) indexes of fit: $\chi^{2}(206, N=$ $1,901)=900.9, p<.001 ; \chi^{2} / d f=4.4, \mathrm{GFI}=.96, \mathrm{IFI}=.98, \mathrm{CFI}=.98, \mathrm{RMSEA}=.04$. The results are presented in Figure 4 . The first hypothesis states that the three dimensions of intangibility will be significantly related to the five dimensions of perceived risk. This hypothesis was partially supported in that only mental intangibility was significantly related to all five dimensions of perceived risk.

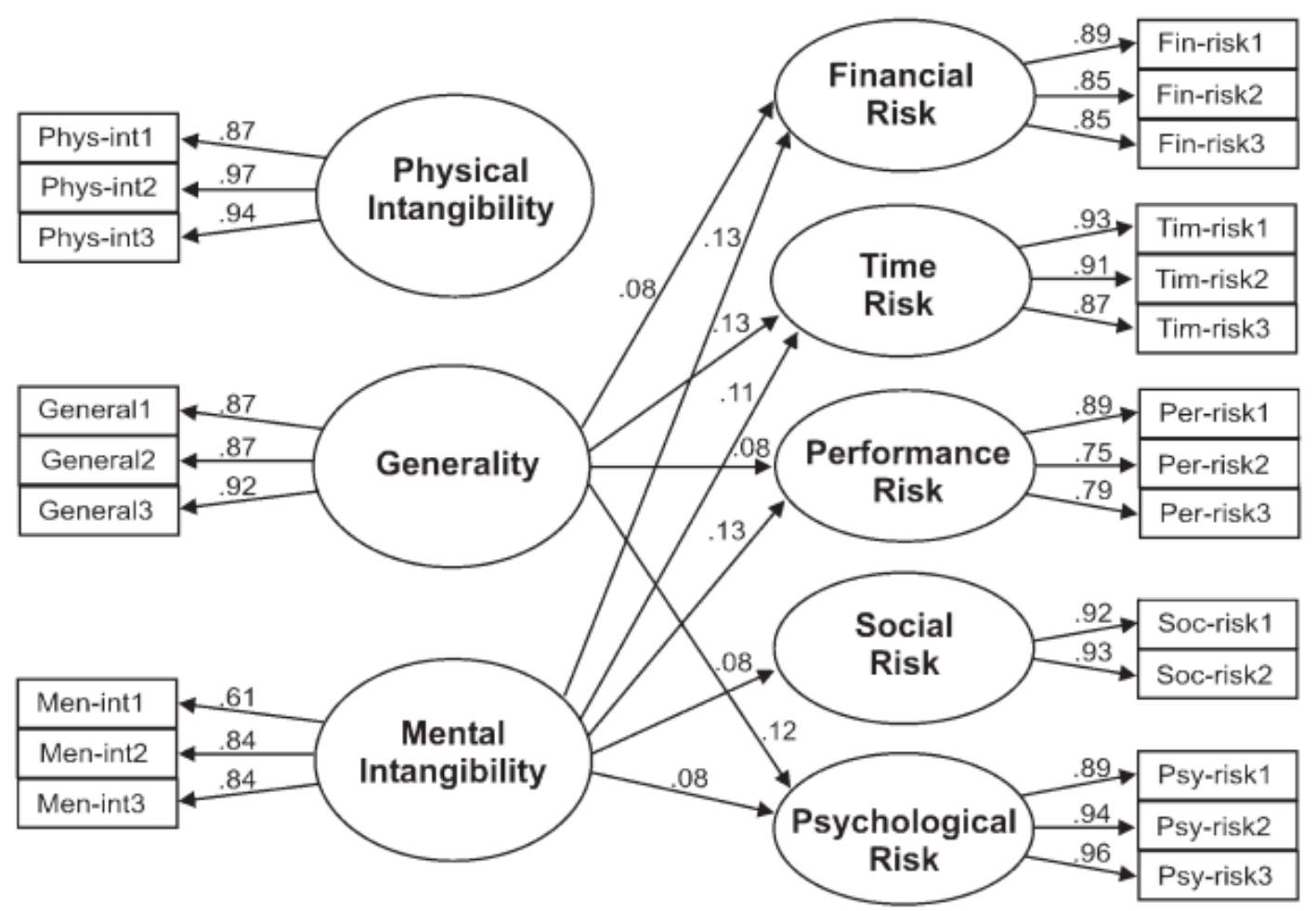

Figure 4. Standardized Results of the Intangibility-Perceived Risk Model

NOTE: Only statistically significant paths $(p<.05)$ are presented here. $\chi^{2}(206, N=1,901)=900.9, p<.001, \chi^{2} / d f=$ 4.4, Goodness-of-Fit Index (GFI) $=.96$, Incremental Fit Index (IFI) $=.98$, Comparative Fit Index (CFI) $=.98$, root mean square error of approximation $($ RMSEA) $=.04$.

Specifically, mental intangibility had a significant effect on financial risk (.13), performance risk (.13), time risk (.11), psychological risk (.08), and social risk (.08) (Figure 4). The consumer's ability to mentally grasp a good or service was the major determinant of the perceived-risk dimensions, relative to either generality or physical intangibility. Because the perception of risk is subjective (Bauer 1960), it follows that mental intangibility would be related to the uncertainty in the mental representation of the good or service. People who are unable to develop a mental representation of the product will have difficulty evaluating it regardless of whether the product has a physical presence or not. 
Generality, the inability to precisely define a particular good, was significantly related to four perceived-risk dimensions, time risk (.13), psychological risk (.12), financial risk (.08), and performance risk (.08), in that order (Figure 4). Recognizing the exploratory nature of this research, it was reasonable to conclude that as generality increased, the consumer perceived that it would take more time to make a decision; put more effort in searching for, and screening of, the appropriate information to make a selection; and felt more difficulty in evaluating the good.

Physical intangibility, the extent to which a good cannot be touched or seen, had no significant impact on any of the risk dimensions $(p>.15)$. At the aggregated level, the (un)availability of physical cues does not dramatically influence any type of risk.

\section{Tests of Hypotheses 2 to 5}

To test the remaining hypotheses, and using EQS, six independent risk models (baseline models) were analyzed for each subsample (i.e., generic products, brands, goods, services, online purchases, offline purchases), and then two additional levels of constraints (i.e., measurement portion and the structural part) were introduced to each pair of models (i.e., generic products vs. brands, goods vs. services, and online purchases vs. offline purchases) to test for their equality (Byrne 1994).

The second hypothesis stated that the intangibility-perceived risk model would have a stronger relationship with generic products versus brands. As hypothesized, the model had a larger standardized coefficient with generic products than with brands in the relationships between generality and three of the five risk dimensions: financial (.18 vs. .06, $p<.05)$, performance $(.12$ vs. .08, $p<.05$ ), and psychological risk (.16 vs. $.12, p=.00$ ), as shown in Table 3 . For the other two risk dimensions, time and social, the causal path differences between brands and generic products were not significant $(p>.15)$. A look at the path coefficients for the mental intangibility-risk relationship showed, however, an opposite phenomenon: The impact of mental intangibility on perceived risk was weaker for generic products versus brands, specifically for financial risk (.09 vs. .18, $p=.02$ ), performance risk ( .12 vs. .16, $p=.01$ ), and psychological risk $(.06$ vs. $.11, p<.05)$. Moreover, all paths from physical intangibility to the five types of risk were insignificant across both categories. Thus, Hypothesis 2 was partially supported.

The argument in support of Hypothesis 2 was that brands help reduce the impact of intangibility on perceived risk. Therefore, in a comparison of the relationship between intangibility dimensions and perceived risk dimensions for generic products versus brands, the generic product model should provide a higher path coefficient than for the brand model. The results offer a partial support for this argument.

Hypothesis 3 stated that physical intangibility would have a greater impact on perceived risks with goods versus services. As expected, most paths between physical intangibility and the perceived-risk dimensions were significant for goods, but none of them were significant for services. There was also a substantial difference between the causal path across the goods and services categories for all five risk dimensions: financial ( .12 vs. . $05, p=.00)$, time (.06 vs. -.03 , $p=.00)$, performance (.10 vs. $-.01, p=.00)$, social ( .27 vs. . $00, p=.00)$, and psychological (.16 vs. $-.05, p=.00$ ) risk (Table 3 ). Thus, Hypothesis 3 was strongly supported. 
Table 3. Results of Invariance Tests for the Intangibility-Perceived Risk Model Across Different Categories

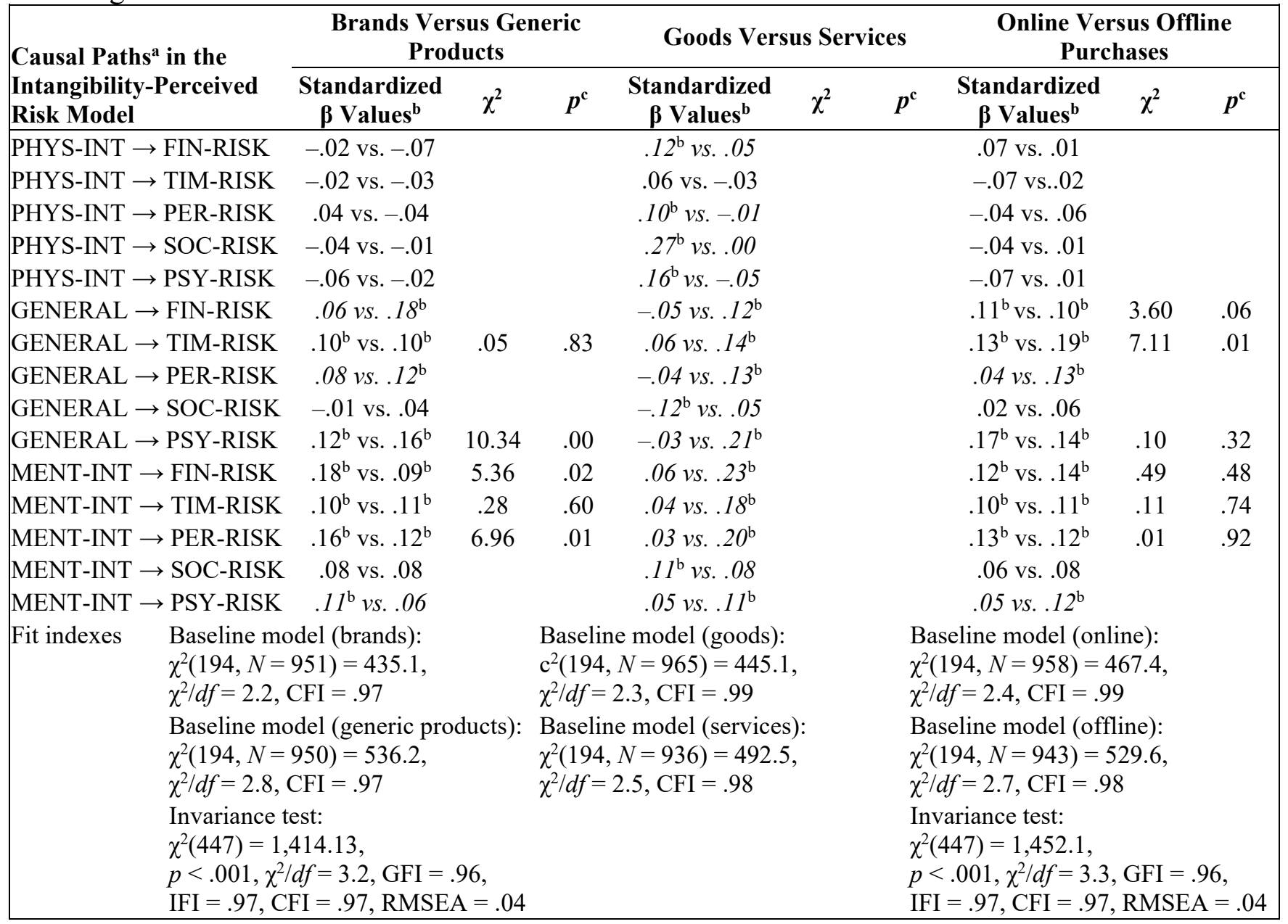

NOTE: CFI = Comparative Fit Index; GFI = Goodness-of-Fit Index; IFI = Incremental Fit Index; RMSEA = root mean square error of approximation.

a. Phys-int $=$ physical intangibility; Ment-int $=$ mental intangibility; General = generality; Fin-risk = financial risk;

Tim-risk $=$ time risk; Per-risk $=$ performance risk; Soc-risk $=$ social risk; Psy-risk $=$ psychological risk .

b. This causal path is statistically significant $(p<.05)$. Asymmetric paths (i.e., causal path significant at one category but not the other) are italicized.

c. Only symmetric paths (i.e., causal path significant at both categories) were compared. Small $p$ values $(p<.05)$ indicated significant invariance between the pair of causal paths.

Hypothesis 4 stated that mental intangibility would have a greater impact on perceived risks with services versus goods. The path coefficients between mental intangibility and the risk dimensions of services were found to be significantly greater than those of goods for four dimensions: financial (.23 vs. $.06, p=.00)$, time (.18 vs. $.04, p=.00)$, performance $(.20$ vs. $.03, p$ $=.00)$, and psychological (.11 vs. $.05, p=.00)$ risk (Table 3$)$. The only exception was between mental intangibility and social risk, in which no significant difference (.08 vs. .11, $p>.05)$ was found, thus lending partial support to Hypothesis 4. 
Mental intangibility was significantly related to four out of the five perceived risk dimensions of services. Because services lack search qualities (Shostack 1977; Zeithaml 1981), it was difficult for consumers to mentally grasp them. Considering the results for goods and services, it would be reasonable to conclude that mental intangibility had a higher impact on perceived risks for services than for goods, whereas physical intangibility had more influence on perceived risks for goods than for services.

Hypothesis 5 stated that the intangibility-perceived risk model would have a weaker relationship with the online situation versus the offline situation. In support of this hypothesis, three of the path coefficients (Table 3) were lower in the online purchase situation than in the offline buying situation: the relationships between generality and time risk (.13 vs. $.19, p=.01)$, generality and performance risk (.04 vs. .13, $p=.00)$, and mental intangibility and psychological risk (.05 vs. $.12, p=.00)$. There was no significant difference in the rest of the relationship paths across two purchase modes (all $p>.05$ ). Therefore, Hypothesis 5 was partially supported.

Cox and Rich (1964) argued that certain forms of shopping may be riskier to the consumer than others, especially those that do not offer visual or tangible cues. This statement does not contradict our results. Our findings suggest that the online environment helps diminish the perceived risk caused by the intangible attributes of the product, which does not necessarily mean the risk level will be lower in the online versus the offline purchase. A review of the mean scores for the five Perceived Risk Scales showed (Table 4) that all five perceived risk dimensions were significantly greater for the online than the offline environments. More interestingly, no significant difference was found in any of the three intangibility scale means across these two purchase situations. In other words, respondents did not perceive any differences in intangibility in the two purchase situations.

Table 4. Mean Scores for the Intangibility and Perceived-Risk Dimensions ${ }^{\mathrm{a}}$

\begin{tabular}{|lcccccc|}
\hline & \multicolumn{2}{c}{ Online } & \multicolumn{2}{c}{ Offline } & & \\
\cline { 2 - 3 } Dimension & $\boldsymbol{M}$ & $\boldsymbol{S D}$ & $\boldsymbol{M}$ & $\boldsymbol{S D}$ & $\boldsymbol{t}$-Value & $\boldsymbol{p}$-Value \\
\hline Intangibility & & & & & & \\
Phys-int & 3.83 & 2.92 & 3.75 & 2.93 & 0.59 & .56 \\
General & 3.83 & 2.31 & 3.90 & 2.31 & -0.68 & .50 \\
Ment-int & 3.23 & 2.19 & 3.21 & 2.14 & 0.20 & .84 \\
Perceived Risk & & & & & & \\
Fin-risk & 3.71 & 2.30 & 2.89 & 2.13 & 8.14 & .00 \\
Rim-risk & 3.64 & 2.30 & 2.54 & 1.88 & 11.38 & .00 \\
Per-risk & 4.35 & 2.35 & 3.42 & 2.16 & 8.98 & .00 \\
Soc-risk & 1.99 & 1.43 & 1.63 & 1.05 & 6.30 & .00 \\
Psy-risk & 2.87 & 2.26 & 1.75 & 1.48 & 12.77 & .00 \\
\hline
\end{tabular}

a. Phys-int $=$ physical intangibility; Ment-int $=$ mental intangibility; General $=$ generality; Fin-risk $=$ financial risk; Tim-risk = time risk; Per-risk = performance risk; Soc-risk = social risk; Psy-risk = psychological risk.

This finding indicates that although intangibility does influence perceived risk in the online environment, it is apparent that other factors might be influencing perceived risk, relative to the offline environment. Here, perceived risk is more likely to be driven by such factors as privacy and security concerns (Hoffman, Novak, and Peralta 1999;Miyazaki and Fernandez, 2001). To better understand the intangibility-perceived risk model in the online environment, it would be 
appropriate to incorporate privacy, security, and other moderators into the model. This would help determine the relative influence of intangibility in the online context.

\section{DISCUSSION}

Intangibility

This study provides theoretical and practical contributions to the service marketing literature. The results confirm that intangibility is a three-dimensional construct, whether in the overall model and across goods and services, generic products and brands, and online and offline purchase situations. Consequently, this Intangibility Scale is a psychometrically sound measure for both theoretical and applied research.

\section{Perceived Risk}

Even though several types of risk were identified in the literature (Jacoby and Kaplan 1972; Roselius 1971), multiple measures of this concept were seldom employed in marketing (Stone and Gronhaug 1993). This research showed that all five dimensions were distinct (Figure 3), thereby lending strong support to the reliability and validity of Stone and Gronhaug's (1993) scale as a measure of perceived risk. Of interest was the relatively low contribution of social risk in all situations (Tables 3). Although it may have reflected, in part, the products selected for the study, the social risk measures probably need to be improved in future research in this area.

Intangibility and Perceived Risk

This research identified a significant strong impact of mental intangibility and generality on most of the risk dimensions (Figure 4). The importance of this finding is that the consumer's ability to mentally grasp a good or service and the consumer's difficulty in precisely defining or describing a particular good are major determinants of the perceived-risk dimensions. This confirmed findings that creating strong mental representations and specific definitions of the product are critical to the tangibilization of services (Breivik, Troye and Olsson 1998; Mittal 2002). If someone does not know what a car engine is made of, the fact that it is a physical object will not be enough to ease the evaluation process. This would also support the strong relationship between mental intangibility/generality and the perceived risk dimensions.

Physical intangibility emerged as the least important dimension of overall intangibility, with significant impact only emerging for goods. This finding is consistent with Breivik, Troye, and Olsson's (1998) study, in which they found that people have less difficulty evaluating physically intangible versus physically tangible goods and services. The rationale behind this fact is that consumers call for mental representations of the product that are resultant of prior knowledge, a process that requires less effort than processing the information derived from tangible attributes (Breivik, Troye and Olsson 1998; Hirschman 1980).

As hypothesized, the intangibility-perceived risk model had a stronger relationship with generic products than with brands for the generality dimension (Table 3). This finding is reasonable because brand names are usually considered as product-specific information. In this sense, brand 
names will facilitate consumers to some extent in their information search process, thus diminishing the effort in forming consideration sets. In line with this discussion, brand names should also enhance mental representations of the products and weaken the impact of mental intangibility on perceived risk. However, an unexpected finding appeared. Mental intangibility was found to have a stronger influence on financial, time, and psychological risks for brand categories than for generic product categories. A possible explanation is that, in the present study, we did not attach the benefits and qualities of the product to the specific brand of each product category. Because there are many brands in each selected product, this would probably make the mental representations of that brand more difficult. Although the reason why brand names of this study, versus generic products, generated a closer relationship between mental intangibility and perceived risk is still unknown, it is obvious that the patterns of the intangibility-perceived risk relationship are different between brands and generic products.

It was hypothesized that the physical (mental) intangibility-perceived risk relationship would be stronger (weaker) with goods versus services. The results lent strong support for the physical intangibility hypothesis (Hypothesis 3 ), but only partial support for the mental intangibility hypothesis (Hypothesis 4). Physical intangibility was significantly related to four out of five perceived-risk dimensions with goods, but none of five paths were found to be significant for services. Mental intangibility, on the other hand, was significantly related to four perceived-risk dimensions only for services. This supports the argument that because services lack search qualities (Shostack 1977; Zeithaml 1981), it is difficult for consumers to mentally grasp them. The fact that physical (mental) intangibility was more closely linked to perceived risk for goods (services) suggests that there are also differences in the intangibility-perceived risk model between goods and services.

The intangibility-perceived risk model was found to have a stronger relationship in the offline versus the online environment. This finding indicates that factors other than intangibility, such as privacy, security concerns, assurance, and trust, are also likely to influence perceived risks in the online environment (Miyazaki and Fernandez 2001; Yoon 2002; Zeithaml, Parasuraman, and Malhotra 2002). For example, Web site trust, which includes security and Web site properties, is significantly related to online purchase intentions and Web site satisfaction (Yoon 2002). Privacy and security concerns have been hypothesized to influence e-service quality and purchase intentions (Zeithaml, Parasuraman, and Malhotra 2000). Although beyond the scope of this article, it is possible that the drivers of perceived risk in the online environment include other dimensions besides intangibility as main effects.

Some authors argue that the Internet, a fairly intangible medium, is currently used as a means of tangibilizing the intangible (Berthon et al. 1999). As an illustration, consider a consumer who wants to visit London for the first time. No matter how much information he or she has gathered from friends and associates, until the visit actually occurs, the visitor will not be able to judge the quality of the experience. The highly acclaimed Strolling Web site (www.strolling.com) allows its visitors to immerse themselves in images of great international cities. The consumer is now able to look at detailed maps of London, clicking on each location to view a 360-degree surround picture or video of the city at that particular point. This type of virtual presence is an excellent example of the Web's ability to tangibilize a previously intangible experience (Berthon et al. 1999). 


\section{MANAGERIAL IMPLICATIONS}

Firms offering high perceived risk goods and/or services can pursue two strategies to reduce consumer risk: implement initiatives that directly address the risk (e.g., guarantees) and/or the factors that contribute to the risk (e.g., increase tangibility). Some of these initiatives are not mutually exclusive but in many cases will be more effective in addressing the cause (intangibility) or the result (perceived risk). An important finding of this research, namely, that intangibility was a significant contributor to perceived risk, indicates there is merit in focusing some marketing initiatives on increasing tangibility. Specifically, on the basis of this research, firms should consider initiatives to increase mental tangibility and specificity.

Firms that can effectively reduce consumers' perceived risk are providing an important source of consumer value, which translates into a competitive advantage. Service marketing strategists have suggested a plethora of tactics to reduce the perception of risks associated with intangible offerings. However, most of these approaches have dealt with physical intangibility. Because it was found that perceived risk was strongly related to the mental dimension of intangibility and generality, as opposed to its physical counterpart, the following implications seek to augment the mental tangibility and specificity of goods and services.

In service settings, many aspects of the service production are not visible to the customer. Letting consumers evaluate and monitor a service production can increase the mental tangibility that customers have of the service provider and thus reduce the perception of risk. For instance, United Parcel Service (UPS) and Federal Express (FedEx) provide tracking numbers for shipments so consumers can use the Internet to know exactly where a package is and what time it arrived at each intermediate and final destination. The U.S. Postal Service does not provide this for Express Mail, which may raise perceived risks for that service.

To increase the tangibility of a mentally intangible and/or general offer, firms could provide information from objective product reviews. Many companies ensure that their salespeople, brochures, and Web sites provide reviews from "neutral" media. Additional information could come from satisfied (or discontented) clients. Saturn, for example, regularly sponsors a gathering of clients who own their vehicle. This strategy would not only increase the clients' mental tangibility and specificity of the offering but also lower the social risk associated with this purchase.

Advertising can play an important role in reducing mental intangibility and generality (Mittal 1999). Strategies can include visualization, creating a vivid mental picture of a service's benefits or qualities (Berry and Clark 1986; Stafford 1996), narratives, focusing on the subjective human experience (Padgett and Allen 1997) and service process episode, and depiction of the service process (Mittal 1999).

The development of brand names for goods and services has also been discussed as a useful method of establishing an image in consumers' minds (Onkvisit and Shaw 1989). Brand names should suggest something about the benefits and qualities of the product and help lower the perceived risks. Some pertinent examples are Federal Express, Pizza Hut, LensCrafters, and 
Comfort Inns. This strategy gives the consumer something mentally tangible and specific with which to associate the service, and it makes the process of pre- and postservice evaluation easier and less risky.

To increase a consumer's mental representation and specificity of a product (and reduce his or her perceived risks), marketers should put much more emphasis on free trial periods. For instance, computer firms such as Microsoft, Adobe, or Macromedia allow consumers to download an updated version of their software for a 30-day trial period. Similarly, car companies offer customers to rent and then apply rental fees to purchase if they decide to buy. One could even benefit from a free trial of the Proquest software and read the Journal of Service Research on one's home computer for a limited period of time.

Due to the extensive and worldwide adoption of the Internet, intangibility will be increasingly present in society. The challenge for marketers might not be so much to increase the physical tangibility of their offering, as has been extensively advocated for the past three decades, but rather to mentally tangibilize and enhance the specificity of their goods and services so that the appropriate risk dimension(s) could be reduced.

\section{LIMITATIONS AND FUTURE RESEARCH}

The limitations of the study include the use of a student sample. Although students are the most convenient respondents available to academic researchers, they do not represent the general adult population. However, for the purpose of theory development, students are considered to be an acceptable sample (Calder, Phillips, and Tybout 1981). Moreover, this population offers the potential advantage of being adapted to future research in the same academic field. Nevertheless, a more realistic environment could involve households instead of students, because they buy more for themselves, have experience in more product categories, and may also have a more precise representation of certain goods and services (Laroche, Bergeron, and Goutaland 2001).

Another limitation is the set of goods and services selected for this study, which might have affected the results. Further empirical examination should include different products. More and more physically intangible products exist in our society, which are often called "information products" (Freiden et al. 1998). Hence, it could be useful to examine the relationship between highly intangible goods (e.g., software) and risk perceptions. It could also prove interesting to investigate goods and services that are known to be extremely risky, such as law services and surgeries.

A third limitation concerns the interesting findings about the online environment that was tested using the paper survey method. Further research should look at testing the relationship between intangibility and perceived risk using an online questionnaire and measuring a number of potential moderators such as privacy and security concerns.

This research extends the understanding of intangibility and perceived risk by using multiple dimensions for both intangibility and perceived risk and by direct modeling to identify the relationships between the individual dimensions of intangibility and perceived risk across goods, services, brands, generic products, and purchase situations. It forms a basis for further research 
on two of the most important variables in marketing and consumer behavior: intangibility and perceived risk.

\section{REFERENCES}

Alba, J. W., J. Lynch, B. Weitz, C. Janiszweski, R. J. Lutz, A. Sawyer, and S. Wood (1997), "Interactive Home Shopping: Consumer, Retailer, and Manufacturer Incentives to Participate in Electronic Marketplaces,” Journal of Marketing, 61 (July), 38-53.

Anderson, J. and D. Gerbing (1988), "Structural Equation Modeling in Practice: A Review and Recommended Two Step Approach,” Psychological Bulletin, 103 (May), 411-423.

Arbuckle, J. (1997), Amos Users' Guide Version 3.6. Chicago: Small Waters Corporation.

Bauer, R. A. (1960), "Consumer Behavior as Risk Taking," in Risk Taking and Information Handling in Consumer Behavior, Donald F. Cox, ed. Cambridge, MA: Harvard University Press, 23-33.

Bebko, C. P. (2000), "Service Intangibility and Its Impact on Consumer Expectations of Service Quality," Journal of Services Marketing, 14 (1), 9-26.

Bentler, P. M. (1992), EQS: Structural Equations Program Manual. Los Angeles: BMDP Statistical Software.

Berry, L. L. (1980), “Services Marketing Is Different,” Business, (May-June), 16-23.

Berry, L. L. (2000), “Cultivating Service Brand Equity,” Journal of the Academy of Marketing Science, 28 (1), 128-137.

Berry, L. L. and T. Clark (1986), “Four Ways to Make a Service More Tangible,” Business, 36 (October-December), 53-54.

Berthon, P., L. Pitt, C. S. Katsikeas, and J. P. Berthon (1999), "Executive Insights: Virtual Services Go International: International Services in the Market space," Journal of International Marketing, 7 (3), 84-105.

Bobbitt, L. M. and P. A. Dabholkar (2001), "Integrating Attitudinal Theories to Understand and Predict Use of Technology-Based Self-Service," International Journal of Service Industry Management, 12 (5), 423-450.

Bollen, K. A. (1989), Structural Equations with Latent Variables. New York: John Wiley.

Breivik, E., S. V. Troye, and U. H. Olsson (1998), "Dimensions of Intangibility and Their Impact on Product Evaluation," working paper, presented at the annual conference of the Association for Consumer Research, October, Montreal, Canada.

Browne, M., and R. Cudeck (1989), "Single Sample Cross Validation Indices for Covariance Structures," Multivariate Behavioral Research, 24, 445-455.

Byrne, B. M. (1994), Structural Equation Modeling with EQS/Windows. Thousand Oaks, CA: Sage. 
Calder, B. J., L. W. Phillips, and A. M. Tybout (1981), "Designing Research for Application," Journal of Consumer Research, 8 (2), 197-208.

Campbell, M. C., and R. C. Goodstein (2001), "The Moderating Effect of Perceived Risk on Consumers' Evaluations of Product Incongruity: Preference for the Norm," Journal of Consumer Research, 28 (3), 439-449.

Cox, D. F., and S. V. Rich (1964), "Perceived Risk and Consumer Decision Making—The Case of Telephone Shopping," in Risk Taking and Information Handling in Consumer Behavior, Donald F. Cox, ed. Cambridge, MA: Harvard University Press, 487-506.

De Ruyter, K., M. Wetzels, and M. Kleijnen (2001), "Customer Adoption of E-service: An Experimental Study," International Journal of Service Industry Management, 12 (2), 184207.

Dowling, G. R. (1999), "Perceived Risk," in The Elgar Companion to Consumer Research and Economic Psychology, Peter E. Earl and Simon Kemp, eds. Cheltenham, UK: Edward Elgar, 419-424.

Dowling, G. R. and R. Staelin (1994), “A Model of Perceived Risk and Risk-Handling Activities," Journal of Consumer Research, 21 (June), 119-134.

Finn, A. (1985), "A Theory of the Consumer Evaluation Process for New Product Concepts," Research in Consumer Behavior, 1, 35-65.

Flipo, J. P. (1988), “On the Intangibility of Services,” The Service Industries Journal, 8 (3), 286300.

Fornell, C. (1983), "Issues in the Application of Covariance Structure Analysis: A Comment," Journal of Consumer Research, 9, 443-448.

Fornell, C. and D. F. Larcker (1981), "Evaluating Structural Equation Models with Unobservable Variables and Measurement Error," Journal of Marketing Research, 18 (2), 39-50.

Freiden, J., R. Goldsmith, S. Takacs, and C. F. Hofacker (1998), "Information as a Product: Not Goods, Not Services," Marketing Intelligence and Planning, 16 (3), 210-220.

Gerbing, D. W. and J. C. Anderson (1993), "Multifaceted Conceptions of Fit in Structural Equation Models," in Testing Structural Equation Models, K. A. Bollen and J. S. Long, eds. Newbury Park, CA: Sage, 10-39.

Gillett, P. L. (1976), “In-home Shoppers: An Overview,” Journal of Marketing, 34, 40-45.

Gorsuch, R. L. (1990), "Common Factor Analysis versus Component Analysis: Some Well and Little Known Facts.” Multivariate Behavioral Research, 25 (1), 33-39.

Havlena, W. J. and W. S. DeSarbo (1990), "On the Measurement of Perceived Consumer Risk," Decision Sciences, 22, 927-939.

Hirschman, Elizabeth C. (1980), "Attributes of Attributes and Layers of Meaning," in Advances in Consumer Research, Vol. 7, Jerry C. Olson, ed. Provo, UT: Association for Consumer Research, 7-12. 
Hoffman, D., P. Novak, and M. Peralta (1999), "Building Consumer Trust Online," Communications of the ACM, 42 (4), 80-85.

Jacoby, J. and L. Kaplan (1972), “The Components of Perceived Risk," in Annual Conference of the Association for Consumer Research, M. Venkatesan, ed. Chicago: Association for Consumer Research, 382-393.

Kaplan, L. B., G. J. Szybillo, and J. Jacoby (1974), “Components of Perceived Risk in Product Purchase,” Journal of Applied Psychology, 59 (June), 287-291.

Laroche, M., J. Bergeron, and C. Goutaland (2001), “A Three-Dimensional Scale of Intangibility," Journal of Service Research, 4 (1), 26-38.

McDougall, G. H. G. (1987), "Determinants of Ease of Evaluation: Products and Services Compared," Canadian Journal of Administrative Sciences, 4 (December), 426-446.

McDougall, G. H. G. and D. W. Snetsinger (1990), "The Intangibility of Services: Measurement and Competitive Perspectives," Journal of Services Marketing, 4 (Fall), 27-40.

Mitchell, V. W. (1999), “Consumer Perceived Risk: Conceptualizations and Models,” European Journal of Marketing, 33 (1/2), 163-195.

Mitchell, V. W. and M. Greatorex (1993), "Risk Perception and Reduction in the Purchase of Consumer Services,” The Service Industries Journal, 13 (October), 179-200.

Mittal, B. (1999), “The Advertising of Services: Meeting the Challenge of Tangibility,” Journal of Service Research, 2 (August), 98-116.

Mittal, B. (2002), "Services Communications: From Mindless Tangibilization to Meaningful Messages," Journal of Services Marketing, 16 (5), 421-431.

Miyazaki, A. D. and A. Fernandez (2001), "Consumer Perceptions of Privacy and Security Risks for Online Shopping,” Journal of Consumer Affairs, 35 (1), 27-44.

Murray, K. B. and J. L. Schlacter (1990), “The Impact of Services Versus Goods on Consumer's Assessment of Perceived Risk and Variability," Journal of the Academy of Marketing Science, 18 (1), 51-65.

Onkvisit, S. and J. Shaw (1989), "Service Marketing: Image, Branding, and Competition," Business Horizons, 32 (1), 13-19.

Oxford Dictionary of Current English (1996), Oxford, UK: Oxford University Press, 438, 460, 931.

Padgett, D. and D. Allen (1997), "Communicating Experiences: A Narrative Approach to Creating Service Brand Image,” Journal of Advertising, 26 (4), 55-62.

Pedhazur, E. and L. Schmelkin (1991), Measurement, Design and Analysis: An Integrated Approach. Hillsdale, NJ: Lawrence Erlbaum.

Peter, J. P. and M. J. Ryan (1976), “An Investigation of Perceived Risk at the Brand Level," Journal of Marketing Research, 13(May), 184-188. 
Roselius, E. (1971), “Consumer Rankings of Risk Reduction Methods," Journal of Marketing, 35 (1), 56-61.

Shostack, G. L. (1977), “Breaking Free from Product Marketing,” Journal of Marketing, 41 (April), 73-80.

Spence, H. E., J. F. Engel, and R. D. Blackwell (1970), "Perceived Risk in Mail Order and Retail Store Buying," Journal of Marketing Research, 7 (August), 364-369.

Stafford, M. R. (1996), “Tangibilityin Service Advertising: An Investigation of Verbal versus Visual Cues," Journal of Advertising, 25 (Fall), 13-28.

Stem, D. E., Jr., C. W. Lamb, and D. L. MacLachlan (1977), "Perceived Risk: A Synthesis," European Journal of Marketing, 11(4), 312-319.

Stone, R. N., and K. Gronhaug (1993), "Perceived Risk: Further Considerations for the Marketing Discipline,” European Journal of Marketing, 27 (3), 39-50.

Taylor, S. and P. A. Todd (1995), "Understanding Information Technology Usage: A Test of Competing Models," Information Systems Research, 6 (June), 144-176.

Thakor, M. V., W. Borsuk-Shtevi, and M. Kalamas (forthcoming), "Hotlists and Web Browsing Behavior-An Empirical Investigation,” Journal of Business Research, 57.

Yoon, S. (2002), "The Antecedents and Consequences of Trust in Online Purchase Decisions," Journal of Interactive Marketing, 16(2), 47-63.

Zeithaml, V. A. (1981), "How Consumer Evaluation Processes Differ between Goods and Services," in The Marketing of Services, Proceedings of the 1981 National Services Conference, J. H. Donnelly and W. R. George, eds. Chicago: American Marketing Association, 186-190.

Zeithaml, V. A. and M. J. Bitner (2000), Services Marketing: Integrating Customer Focus across the Firms, 2nd ed. New York: McGraw-Hill.

Zeithaml, V. A., A. Parasuraman, and A. Malhotra (2000), “A Conceptual Framework for Understanding e-Service Quality: Implications for Future Research and Managerial Practice," Report No. 00-115, Marketing Science Institute, Cambridge, MA.

Zeithaml, V. A., A. Parasuraman, and A. Malhotra (2002), "Service Quality Delivery through Web Sites: A Critical Review of Extant Knowledge," Journal of the Academy of Marketing Science, 30 (4), 362-375. 


\section{APPENDIX A}

Measures and Reliability Analyses

\begin{tabular}{|c|c|c|}
\hline \multicolumn{2}{|l|}{ Constructs/Measures $^{\text {a }}$} & Cronbach $\alpha$ \\
\hline Intangibility (ITANG) ${ }^{b}$ & & .95 \\
\hline \multicolumn{3}{|l|}{ Physical Intangibility } \\
\hline PHYS-INT1 ${ }^{\mathrm{c}}$ & This item is very easy to see and touch. & \\
\hline PHYS-INT2 ${ }^{c}$ & I can physically grasp this item. & \\
\hline PHYS-INT3 ${ }^{c}$ & This item is very tangible. & \\
\hline Generality & & .91 \\
\hline GENERAL1 ${ }^{\mathrm{c}}$ & I could easily explain many features associated with this item. & \\
\hline GENERAL2 ${ }^{\mathrm{c}}$ & It is not difficult to give a precise description of this item. & \\
\hline GENERAL $3^{\mathrm{c}}$ & It is easy to describe many features related to this item. & \\
\hline \multicolumn{3}{|l|}{ Mental Intangibility } \\
\hline MENT-INT1 & $\begin{array}{l}\text { I need more information about this item in order to make myself a clear idea } \\
\text { of what it is. }\end{array}$ & .80 \\
\hline MENT-INT2 & This is a difficult product to think about. & \\
\hline MENT-INT3 & This is not the sort of product that is easy to picture. & \\
\hline \multicolumn{3}{|l|}{ Perceived Risk (RISK) ${ }^{b}$} \\
\hline Financial Risk & & .90 \\
\hline FIN-RISK1 & $\begin{array}{l}\text { If I bought an item for myself within the next } 12 \text { months, I would be } \\
\text { concerned that the financial investment I would make would not be wise. }\end{array}$ & \\
\hline FIN-RISK2 & Purchasing this item could involve important financial losses. & \\
\hline FIN-RISK3 & $\begin{array}{l}\text { If I bought an item for myself within the next } 12 \text { months, I would be } \\
\text { concerned that I would not get my money's worth. }\end{array}$ & \\
\hline Time-Risk & & .91 \\
\hline TIM-RISK1 & Purchasing an item could lead to an inefficient use of my time. & \\
\hline TIM-RISK2 & Purchasing an item could involve important time losses. & \\
\hline TIM-RISK3 & $\begin{array}{l}\text { The demands on my schedule are such that purchasing an item concerns me, } \\
\text { because it could create even more time pressures on me that I don't need. }\end{array}$ & \\
\hline Performance Risk & & .88 \\
\hline PER-RISK1 & $\begin{array}{l}\text { If I were to purchase an item within the next } 12 \text { months, I would become } \\
\text { concerned that the item will not provide the level of benefits that I would be } \\
\text { expecting. }\end{array}$ & \\
\hline PER-RISK2 & $\begin{array}{l}\text { As I consider the purchase of an item soon, I worry about whether it will } \\
\text { really "perform" as well as it is supposed to. }\end{array}$ & \\
\hline PER-RISK3 & $\begin{array}{l}\text { The thought of purchasing an item causes me to be concerned for how really } \\
\text { reliable that product will be. }\end{array}$ & \\
\hline Social Risk & & .92 \\
\hline SOC-RISK $1^{c}$ & If I bought an item, I think I would be held in higher esteem by my friends. & \\
\hline SOC-RISK2 ${ }^{\mathrm{c}}$ & If I bought an item, I think I would be held in higher esteem by my family. & \\
\hline Psychological Risk & & .95 \\
\hline PSY-RISK1 & The thought of purchasing an item gives me a feeling of unwanted anxiety. & \\
\hline PSY-RISK2 & $\begin{array}{l}\text { The thought of purchasing an item makes me feel psychologically } \\
\text { uncomfortable. }\end{array}$ & \\
\hline PSY-RISK3 & $\begin{array}{l}\text { The thought of purchasing an item causes me to experience unnecessary } \\
\text { tension. }\end{array}$ & \\
\hline
\end{tabular}

a. The term item was replaced with the appropriate product in the surveys. Each question was rephrased in accordance to the proper product.

b. Each question was measured on a 9-point Likert-type scale (strongly disagree to strongly agree).

c. This item was reversed. 


\section{APPENDIX B}

Means and Standard Deviations of Goods and Services Ratings Using Intangibility and Perceived Risk Scales

\begin{tabular}{|c|c|c|c|c|c|c|c|c|c|c|c|c|c|c|c|c|}
\hline & \multicolumn{2}{|c|}{$\begin{array}{c}\text { Physical } \\
\text { Intangibility }\end{array}$} & \multicolumn{2}{|c|}{ Generality } & \multicolumn{2}{|c|}{$\begin{array}{c}\text { Mental } \\
\text { Intangibility }\end{array}$} & \multicolumn{2}{|c|}{ Financial Risk } & \multicolumn{2}{|c|}{ Time Risk } & \multicolumn{2}{|c|}{$\begin{array}{c}\text { Performance } \\
\text { Risk }\end{array}$} & \multicolumn{2}{|c|}{ Social Risk } & \multicolumn{2}{|c|}{$\begin{array}{c}\text { Psychological } \\
\text { Risk }\end{array}$} \\
\hline & $M$ & $S D$ & $M$ & $S D$ & $M$ & $S D$ & $M$ & $S D$ & $M$ & $S D$ & $M$ & $S D$ & $M$ & $S D$ & $M$ & $S D$ \\
\hline Jeans & 1.95 & 1.36 & 2.92 & 1.80 & 2.38 & 1.76 & 3.30 & 2.24 & 2.99 & 2.20 & 4.50 & 2.43 & 1.53 & 0.83 & 2.18 & 1.20 \\
\hline CDs & 2.00 & 1.67 & 3.57 & 2.32 & 2.56 & 1.79 & 2.57 & 1.91 & 2.88 & 2.21 & 2.72 & 1.74 & 2.00 & 1.45 & 2.06 & 1.78 \\
\hline Computers & 2.39 & 1.68 & 3.58 & 2.05 & 2.89 & 1.96 & 4.54 & 2.27 & 3.26 & 1.96 & 4.35 & 2.26 & 2.38 & 1.56 & 2.86 & 2.19 \\
\hline Pizzeria dinners & 2.61 & 2.08 & 2.91 & 2.03 & 2.70 & 1.95 & 2.54 & 2.12 & 2.88 & 2.27 & 3.70 & 2.45 & 1.29 & 0.65 & 1.90 & 1.76 \\
\hline Internet browsers & 6.62 & 2.25 & 5.20 & 2.29 & 4.41 & 2.37 & 3.53 & 2.14 & 3.35 & 1.99 & 4.12 & 2.10 & 1.86 & 1.26 & 2.25 & 1.77 \\
\hline Checking accounts & 7.06 & 2.37 & 4.92 & 2.23 & 4.32 & 2.06 & 3.30 & 2.23 & 3.18 & 2.25 & 4.01 & 2.39 & 1.77 & 1.27 & 2.62 & 2.23 \\
\hline
\end{tabular}

